\title{
Correction to: Consumer Protection Technologies: An Investigation Into the Potentials of New Digital Technologies for Consumer Policy
}

\author{
C. Thorun $^{1} \cdot$ J. Diels ${ }^{1}$
}

Published online: 13 April 2019

(C) Springer Science+Business Media, LLC, part of Springer Nature 2019

\section{Correction to: Journal of Consumer Policy (COPO) https://doi.org/10.1007/s10603-019-09411-6}

The original article unfortunately contains error in the article title.

The correct article title is presented above.

The original article has been corrected.

Publisher's Note Springer Nature remains neutral with regard to jurisdictional claims in published maps and institutional affiliations.

The online version of the original article can be found at https://doi.org/10.1007/s10603-019-09411-6

C. Thorun

thorun@conpolicy.de

J. Diels

diels@ conpolicy.de

1 ConPolicy, Institute for Consumer Policy, Berlin, Germany 